\title{
Role of TNF $\alpha$ in the induction of antigen induced arthritis in the rabbit and the anti-arthritic effect of species specific $\mathrm{TNF} \alpha$ neutralising monoclonal antibodies
}

\author{
Jo Lewthwaite, Simon Blake, Timothy Hardingham, Roland Foulkes, Sue Stephens, \\ Lesley Chaplin, Spencer Emtage, Cath Catterall, Steven Short, Andrew Nesbitt, \\ Rodger Allen, Mark Bodmer, Derek Brown, David Andrew, Brian Henderson
}

\begin{abstract}
Objective-To investigate the role of tumour necrosis factor $\alpha$ (TNF $\alpha)$ in the development of antigen induced arthritis (AIA) in rabbits.

Methods-Monoclonal antibodies to rabbit TNF $\alpha$ were developed in rats and were used to detect TNF $\alpha$ in synovial fluid by enzyme linked immunosorbent assay and to localise it in tissue sections of synovium and cartilage from rabbits up to 21 days after induction of AIA. An antibody which neutralised TNF $\alpha$ activity in vitro was injected into rabbits to block TNF $\alpha$ action in vivo in AIA. Joint swelling, leucocyte infiltration into synovium and proteoglycan loss from cartilage were measured and compared with a control group, which were injected with sterile saline.
\end{abstract}

Results-Monoclonal antibodies to purified rabbit TNF $\alpha$ were prepared in rats and two were selected which were able to neutralise rabbit TNF $\alpha$ in a cytotoxicity bioassay. TNF $\alpha$ was detected in significant concentrations $(21 \cdot 7(\mathrm{SE} 0 \cdot 5) \mathrm{pg} / \mathrm{ml})$ in the arthritic joint fluid of rabbits with AIA only at one day after induction and it was then also sparsely localised in cells of the synovium, but from day 3 onwards it was localised more strongly in the deep zone of articular cartilage. Injection of anti-TNF monoclonal antibody $R 6$ over three days into rabbits with AIA reduced joint swelling and leucocyte infiltration into joint fluid and decreased the expression of CD11b and CD18 on cells in the joint fluid. However, there was no significant reduction in the loss of proteoglycan from articular cartilage, although the joint fluid at three days contained a lower glycosaminoglycan content. The antibody $\mathrm{R} 6$ gave most effect at a dose of $0.6 \mathrm{mg} / \mathrm{kg}$ and there was no increase in its effectiveness at a fivefold greater dose (3.0 $\mathrm{mg} / \mathrm{kg})$. Treatment over 10 days gave a more complete suppression of joint swelling, but did not result in any less proteoglycan loss from cartilage. Treatment for five days with a 16 day follow up gave a significant reduction in swelling for several days beyond the treatment, but the swelling then slowly returned, until by day 21 there was no significant difference in joint swelling and there was also no recovery of cartilage proteoglycan content. A rabbit anti-rat immunoglobulin response was detected at 21 days, which may have limited the long term effectiveness of the antibody.

Conclusions-In AIA in rabbits, TNF $\alpha$ was only detected in synovial fluid at one day after induction and there was only limited cellular localisation of $\mathrm{TNF} \alpha$ in synovium and cartilage from three days. However, neutralising TNF $\alpha$ with a monoclonal antibody was effective in suppressing inflammatory changes in the joint during the acute onset of AIA, but it had little effect on the loss of proteoglycan from cartilage. The results suggest that blocking inflammation and synovitis with antiTNF $\alpha$ may be more easily achieved than preventing damage to articular cartilage.

(Ann Rheum Dis 1995; 54: 366-374)

The pro-inflammatory cytokines, tumour necrosis factor $\alpha(\mathrm{TNF} \alpha)$ and interleukin-1 (IL-1), are believed to be important mediators in the pathology of inflammatory joint diseases such as rheumatoid arthritis (RA). They have various activities demonstrated in vitro, such as stimulation of prostanoid and metalloproteinase synthesis, ${ }^{1}$ upregulation of vascular endothelial cell adhesiveness, ${ }^{2}$ stimulation of the breakdown of articular cartilage and bone in culture $^{34}$ and stimulation of fibroblast proliferation and collagen synthesis. ${ }^{5}$ Both cytokines have been identified in the joint fluid and synovial tissues of RA patients ${ }^{6-8}$ and the development of arthritic lesions in the joints of a transgenic mouse expressing human $\mathrm{TNF} \alpha$ has been shown to be prevented by antibodies to TNF $\alpha .{ }^{9}$ Injection of IL-1 or TNF $\alpha$ into the knee joints of rabbits induced synovitis ${ }^{1011}$ and, in the case of IL-1, also caused the loss of articular cartilage proteoglycan. Injection of both IL-1 and TNF $\alpha$ into rabbit knee joints gave a synergistic increase in the numbers of polymorphonuclear leucocytes entering the joint cavity. ${ }^{11}$

To determine the role of these proinflammatory cytokines in the development of antigen induced arthritis (AIA), we have investigated the effects of cytokine blockade, 
initially using recombinant human IL-1 receptor antagonist (IL-1 ra) to block the action of IL- $1 .^{12}$ In a preliminary study, by the preadministration of IL-1ra we were able to inhibit completely the synovitis and loss of cartilage proteoglycan in the rabbit knee joint induced by the single injection of $25 \mathrm{ng}$ of recombinant IL-1. ${ }^{12}$ However, IL-1 ra at a similar dose was unable to inhibit either the synovitis, or the cartilage proteoglycan loss found in the acute phase of AIA in the rabbit. ${ }^{13}$ In this model, a chronic monoarticular inflammatory lesion develops, which closely resembles rheumatoid arthritis in terms of its synovial histopathology and biochemistry ${ }^{14}$ and in its response to anti-arthritic drugs. ${ }^{15}$

In the present study we have produced and characterised a number of rat antibodies to rabbit $\mathrm{TNF} \alpha$ which bind and block its bioactivity. We have used one of these antibodies to determine the anti-inflammatory and anti-arthritic actions of neutralising $\mathrm{TNF} \alpha$ in rabbits with acute AIA. To relate this to the expression of TNF $\alpha$ in AIA, we have determined the concentrations of bioactive TNF $\alpha$ in the joints fluids and the immunocytochemical localisation of TNF $\alpha$ in the synovium and in the articular cartilage of control and inflamed joints during the first 21 days after the induction of arthritis.

\section{Materials and methods}

PURIFICATION OF RABBIT TNF $\alpha$

Increased expression of $\mathrm{TNF} \alpha$ was induced in 14 rabbits by intravenous injection of BCG vaccine $\left(10^{8}\right.$ organisms, Evans, Liverpool, UK) followed two weeks later by an intravenous injection of $100 \mu \mathrm{g}$ lipopolysaccharide (E. coli 0111.B4, Sigma). After 90 minutes, blood was collected and yielded $600 \mathrm{ml}$ of serum, which contained $12 \mu \mathrm{g} / \mathrm{ml} \mathrm{TNF} \alpha$ when assayed by the the $\mathrm{L} 929$ cytotoxicity assay ${ }^{16}$ with a recombinant human $\mathrm{TNF} \alpha$ standard. The $\mathrm{TNF} \alpha$ was purified by techniques based on previously published methods. ${ }^{17-19}$ Briefly, this involved a diethylaminoethyl Sepharose Fast Flow ion exchange chromatography step with a sodium chloride gradient. The TNF $\alpha$ fractions were pooled, concentrated and chromatographed on an AcA44 gel filtration column. The TNF $\alpha$ fractions, stabilised by the addition of $50 \%$ $(\mathrm{v} / \mathrm{v})$ glucose, were loaded onto a concanavalin-A Sepharose column and collected as the flow through from the column and then applied to a Mono $\mathrm{Q}$ fluid phase liquid chromatography column eluted with a sodium chloride gradient. The TNF $\alpha$ actions were pooled, concentrated and yielded $600 \mu \mathrm{g}$ of bioactive $T N F \alpha$. This material was used for the immunisation of rats.

CLONING AND EXPRESSION OF RABBIT TNF $\alpha$ The gene for rabbit TNF $\alpha$ was cloned from rabbit spleen DNA by polymerase chain reaction using oligonucleotide primers based on the sequence of Ito et al. ${ }^{20}$ Analysis of the cloned DNA revealed a sequence in complete agreement with that described by Ito's group, except for nucleotide 485, in which we found a guanine (G) instead of a cytosine (C). For expression, the gene encoding mature rabbit $\mathrm{TNF} \alpha$ was ligated into the vector $\mathrm{pMG} 196^{21}$ downstream of the trp promoter, using Cla1 and $E c o R 1$ adapters and then transformed into $E$ coli $\mathrm{XL1-blue.} \mathrm{From} \mathrm{induced} \mathrm{cultures,} \mathrm{cells} \mathrm{were}$ harvested and lysed by sonication. TNF $\alpha$ was purified by affinity chromatography on an antirabbit TNF $\alpha$ (R2) column prepared by coupling antibody to amino link gel (Pierce, UK). The $\mathrm{TNF} \alpha$ was eluted with $3 \mathrm{~mol} / \mathrm{MgCl} \mathrm{Mg}_{2}$ and was stored after dialysis in $50 \mathrm{mmol} / \mathrm{l}$ Tris- $\mathrm{HCl}$ $\mathrm{pH} 7 \cdot 5,150 \mathrm{mmol} / 1 \mathrm{NaCl}, 0.05 \%$ (v/v) Brij 35 detergent (Sigma) at $-70^{\circ} \mathrm{C}$.

PREPARATION OF NEUTRALISING MONOCLONAL ANTIBODIES TO RABBIT TNF $\alpha$

Lou/c rats were immunised by serial intraperitoneal injections of purified rabbit $\mathrm{TNF} \alpha$ (25 $\mu \mathrm{g}$ /animal in multiple sites) over a period of three months. Spleen cells from immunised rats were prepared three days after an intravenous injection of $25 \mu \mathrm{g} \mathrm{TNF} \alpha$ and were fused to mouse $\mathrm{Sp} 2 / 0$ myeloma cells to produce a panel of monoclonal antibody (MAb)-secreting hybridomas. The hybridomas were screened for the production of MAbs able to neutralise rabbit $\mathrm{TNF} \alpha$ in the $\mathrm{L} 929$ bioassay. ${ }^{19}$ Two cells lines termed R2 and R6 (both rat IgG1 subclass) were chosen for large scale production of antibodies, which were purified by protein-A-Sepharose affinity chromatography as described previously, ${ }^{22}$ except that the equilibration buffer contained $4 \mathrm{~mol} / 1 \mathrm{NaCl}$. The product was $>95 \%$ pure by sodium dodecyl sulphate polyacrylamide gel electrophoresis and was low in endotoxin (0.07 EU/mg antibody).

PHARMACOKINETICS OF ANTI-TNF $\alpha$ ANTIBODY Male New Zealand white rabbits $(1 \cdot 8-2 \cdot 2 \mathrm{~kg})$ were given R6 $3 \mathrm{mg} / \mathrm{kg}$ either intravenously or intramuscularly as a single bolus in $0.5 \mathrm{ml}$ sterile saline. Blood samples were collected before injection of antibody and at various times from 15 minutes to 28 days after the injection. Plasma concentrations of R6 were detected using a sandwich enzyme linked immunosorbent assay (ELISA). Microtitre plates were coated with a rabbit anti-rat IgG (Sigma). Diluted samples of serum were then added in duplicate, incubated for 24 hours, and the bound rat antibody visualised using a horseradish peroxidase (HRP)-conjugated goat anti-rat Fc.

ELISA ASSAY FOR RABBIT TNF $\alpha$

Microtitre plates were coated with the R2 antibody to rabbit $\mathrm{TNF} \alpha$ and the rabbit $\mathrm{TNF} \alpha$ bound to the plate was detected by addition of a biotin-conjugated second anti-TNF $\alpha$ antibody (R6). HRP-streptavidin was then added and bound enzyme was determined using 3,3',5,5'-tetramethylbenzidine substrate and hydrogen peroxide. This assay was standardised with recombinant rabbit $\mathrm{TNF} \alpha$ prepared 
as described above. In some studies the immunoreactivity in samples was compared with the bioactivity as assessed by the L929 cytotoxicity assay. ${ }^{19}$

MEASUREMENT OF RABBIT ANTI-RAT IgG ANTIBODY RESPONSE

The levels of circulating rabbit antibodies to the rat MAb R6 were measured by a two site ELISA. Antibody R6 was coated to the plate and biotinylated $\mathrm{R} 6$ or a biotinylated rat antibody with reactivity against an unrelated antigen (human lymphotoxin) was used for detection. After addition of the biotinylated antibody and washing, the amount of bound rabbit anti-rat IgG was determined using HRP-streptavidin as described above. The assay as standardised by use of a commercially available rabbit anti-rat IgG antiserum (Sigma). Results using either biotinylated second antibody were similar.

INDUCTION OF ANTIGEN INDUCED ARTHRITIS Adult female New Zealand white rabbits $(2 \cdot 2-2.5 \mathrm{~kg})$ were immunised with Freund's complete adjuvant (Difco) $(1 \mathrm{ml})$ containing $5 \mathrm{mg}$ ovalbumin (Sigma) given intradermally in multiple sites and re-immunised 14 days later. After a further seven days, arthritis was induced by injecting ovalbumin $(5 \mathrm{mg}$ in $1 \mathrm{ml}$ sterile saline) into the left knee joint. The contralateral control knee was injected with saline.

In one experiment animals were investigated in groups $(n=3)$ at one, three, seven, 14 and 21 days after the induction of arthritis. The concentration of TNF $\alpha$ in the joint fluid was measured by ELISA and the cellular localisation of the TNF $\alpha$ determined by immunocytochemistry on cryostat sections of articular cartilage and synovium.

TREATMENT OF RABBITS WITH ANTI-RABBIT TNF $\alpha$ MONOCLONAL ANTIBODY R6

Four experiments were conducted using antiTNF R6 in a total of 66 animals. All experiments were conducted in full accordance with current UK Home Office regulations on the handling of animals.

Rabbits were administered antibody intravenously two hours before the intra-articular injection of ovalbumin which initiated the arthritis, and then 24 and 48 hours after this challenge; the experiment was terminated at 72 hours. In two experiments, rabbits were given injections of $0 \cdot 12,0 \cdot 6$, or $3 \mathrm{mg} / \mathrm{kg}$ of antibody R6. In further experiments to determine the effect of prolonged therapy, animals were given $0.6 \mathrm{mg} / \mathrm{kg} \mathrm{R} 6$ daily for 10 days between one and 10 days after induction of arthritis and the experiment was terminated on day 11 (that is, 24 hours after the last dose of R6). To determine whether the effects of therapy were prolonged, in further experiments animals were given $0.6 \mathrm{mg} / \mathrm{kg} \mathrm{R} 6$ daily for five days from one to five days after induction of arthritis and the experiment was terminated at day 21 ( 16 days after the last dose of antibody).
ASSESSMENT OF ARTHRITIS

The development and severity of arthritis was determined by measuring (once or twice daily) the diameters of the control and arthritic knee joints at the midline of the joint with the leg flexed at an angle of $45^{\circ}$. The value for the control joint was subtracted from that of the arthritic joint to give the joint swelling. Animals were given an overdose of sodium pentobarbitone at the termination of all experiments and blood was taken by cardiac puncture into heparinised tubes to provide plasma for $\mathrm{TNF} \alpha$ and anti-TNF $\alpha$ antibody measurements. The joints were injected with $1.5 \mathrm{ml}$ of sterile saline and then flexed to mix the contents of the synovial cavity and the resultant joint fluid, containing infiltrating leucocytes, was aspirated in a sterile syringe. Cells were collected by centrifugation (400 $g$ for 30 seconds) and resuspended in phosphate buffered saline (PBS) and counted in a haemocytometer. The cell free joint fluid was immediately frozen and stored at $-20^{\circ} \mathrm{C}$ for subsequent analysis.

\section{HISTOPATHOLOGY OF JOINT TISSUES}

The infrapatellar fat pad was dissected from both the arthritic and contralateral control knee joints. Sections $(5 \mu \mathrm{m})$ were cut from paraffin wax blocks of tissue fixed in formal buffered saline and stained with haematoxylin and eosin. Other blocks of synovial lining were chilled in $\mathrm{n}$-hexane at $-70^{\circ} \mathrm{C}$ for cryostat sections. The femur was removed from the bone shaft, cut in half lengthways, and chilled in $\mathrm{n}$-hexane at $-70^{\circ} \mathrm{C}$. Combined sections of bone and cartilage were cut from undecalcified blocks using a Bright 3050 heavy duty cryostat and were stained with haematoxylin and eosin.

Cryostat sections $(10 \mu \mathrm{m})$ of rabbit synovium and of the ends of the femurs were fixed in acetone and endogenous peroxidase was blocked with methanolic hydrogen peroxide. The sections were incubated with antibody R6 for four hours at room temperature, then with biotinylated goat anti-rat IgG antiserum ( 1 in 100) for 30 minutes, and then StreptavidinABC complex (Dako). Peroxidase activity was detected by addition of diaminobenzidine- $\mathrm{HCl}$ and hydrogen peroxide. Sections were counterstained with Mayer's haematoxylin. Serial sections were also stained using an indirect alkaline phosphatase technique. ${ }^{23}$

\section{FLUORESCENCE ACTIVATED CELL SORTING} ANALYSIS

Approximately $2 \times 10^{6}$ cells from each arthritic joint fluid were fixed in PBS containing 4\% paraformaldehyde (BDH) for 20 minutes at room temperature. The fixed cells were washed twice in PBS containing fetal calf serum $(2 \% \mathrm{w} / \mathrm{v})$ and sodium azide $(0 \cdot 1 \% \mathrm{w} / \mathrm{v})$ and then resuspended in $1 \mathrm{ml}$ of this solution at $4^{\circ} \mathrm{C}$. For immunolocalisation, cells were incubated for 30 minutes at $4^{\circ} \mathrm{C}$ with the antirabbit CD18 (monoclonal 6.5E) or anti-rabbit CD11b (monoclonal 198), (kindly provided by Dr Martyn Robinson, Celltech Research). The 
cells were then incubated with fluoresceinconjugated goat anti-mouse secondary antibody ( 1 in 500) and analysed for fluorescence intensity using a FACScan flow cytometer (Beckton Dickinson, Mountain View, CA). The number of positive cells was determined by comparison with a control using an antibody of similar isotype which showed no specific binding to rabbit cells.

PROSTAGLANDIN $E_{2}\left(\mathrm{PGE}_{2}\right)$ ASSAY

The $\mathrm{PGE}_{2}$ concentration in the synovial aspirates of control and arthritic joints was measured with a commercial radioimmunoassay (New England Nuclear).

CARTILAGE PROTEOGLYCAN LOSS

The loss of proteoglycan from articular cartilage was assessed by measuring the glycosaminoglycan (GAG) content of the joint fluid. Aliquots of joint fluid were digested with papain at $60^{\circ} \mathrm{C}$ for 18 hours, followed by a further treatment with one unit of hyaluronidase (Streptomyces hyaluronate lyase, Calbiochem) at $37^{\circ} \mathrm{C}$ and the concentration of sulphated GAGs was measured by an automated modification ${ }^{24}$ of the 1,9-dimethylmethylene blue binding assay. ${ }^{25}$

Full thickness slices of articular cartilage were dissected from the femoral condyles and tibial plateaus of both arthritic and control joints. The cartilage was collected (into preweighed vials), weighed and digested with papain for 18 hours at $60^{\circ} \mathrm{C}$ and the concentration of sulphated GAGs determined. ${ }^{25}$ The proteoglycan content of the cartilage was expressed as $\mu \mathrm{g}$ of GAG per mg wet weight of the original cartilage.

STATISTICAL ANALYSIS

The results were expressed as mean (SE). Statistical significance of data comparing saline with anti-TNF $\alpha$ treated rabbits was determined by the Mann-Whitney $U$ test.

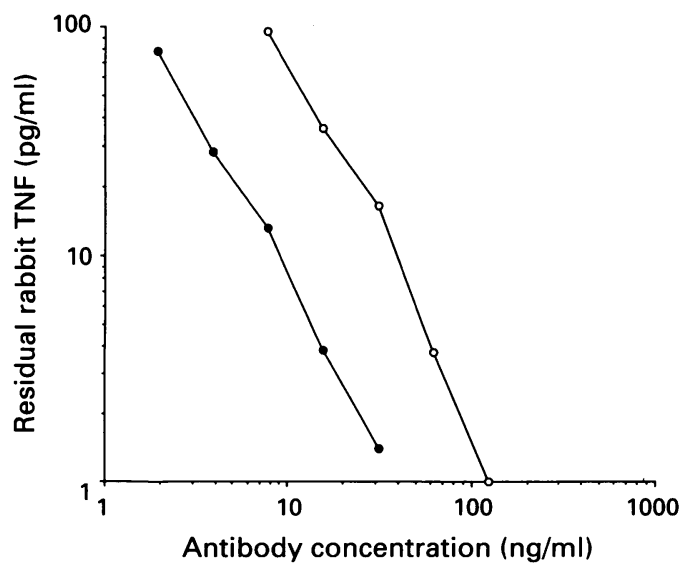

Figure 1 Ability of rat monoclonal antibodies $R 2(\mathrm{O})$ and R6 (O) to neutralise rabbit TNF $\alpha$ bioactivity in the L929 cytotoxicity assay. Results are means of six replicate cultures.

\section{Results}

NEUTRALISING TNF $\alpha$ MONOCLONAL ANTIBODIES Figure 1 shows the potency of the two antibodies compared in the L929 cytotoxicity bioassay. ${ }^{19}$ Antibody R6 inhibited $50 \%$ of the TNF bioactivity at a concentration of $3 \mathrm{ng} / \mathrm{ml}$, while antibody R2 inhibited $50 \%$ at $12 \mathrm{ng} / \mathrm{ml}$. The mean difference for a number of experiments showed that R6 was four to five times more effective than $\mathrm{R} 2$ in neutralising rabbit $\mathrm{TNF} \alpha$.

Intravenous injection of R6 into two rabbits gave a maximum plasma concentration within 30 minutes of $104 \mu \mathrm{g} / \mathrm{ml}$ and $70 \mu \mathrm{g} / \mathrm{ml}$ and circulating half life times of 29.9 hours and $28 \cdot 2$ hours. Intramuscular injection into two additional rabbits resulted in smaller, but more prolonged plasma concentrations $(19 \mu \mathrm{g} / \mathrm{ml}$ and $15 \mu \mathrm{g} / \mathrm{ml}$ at 48 hours).

INDUCTION OF ARTHRITIS AND DETECTION OF TNF $\alpha$

The time course of induction of arthritis was followed from one to 21 days after intraarticular challenge with ovalbumin. There was a rapid swelling in the arthritic joints, which was maximal at day $1(5 \cdot 1(\mathrm{SE} 0.5) \mathrm{mm})$, after which the acute swelling declined until it reached a plateau at day $7(2-3 \mathrm{~mm})$, which was maintained for the duration of the arthritis. Examination of stained sections of synovium revealed histopathological changes associated with acute inflammation, which gave way to chronic synovitis and fibrosis as reported previously in the animal model of arthritis. ${ }^{14}$ Over the 21 day period of arthritis, immunoreactive $T N F \alpha$ concentrations were found in the joint fluid only at one day after the induction $(21.7(0.5) \mathrm{pg} / \mathrm{ml})$.

In the inflamed synovium of the arthritic joints, small numbers of macrophage-like cells in the subintima showed immunoreactivity for TNF $\alpha$ from day 3 onwards, but no TNF $\alpha$ was detected in the synovial lining cell layer. In contrast, the articular cartilage showed greatest $\mathrm{TNF} \alpha$ localisation. By day 3 there was staining with both antibodies R2 and R6 in the articular cartilage, which was restricted to the chondrocytes in the deep zone adjacent to the subchondral bone (fig 2). From day 7 there was

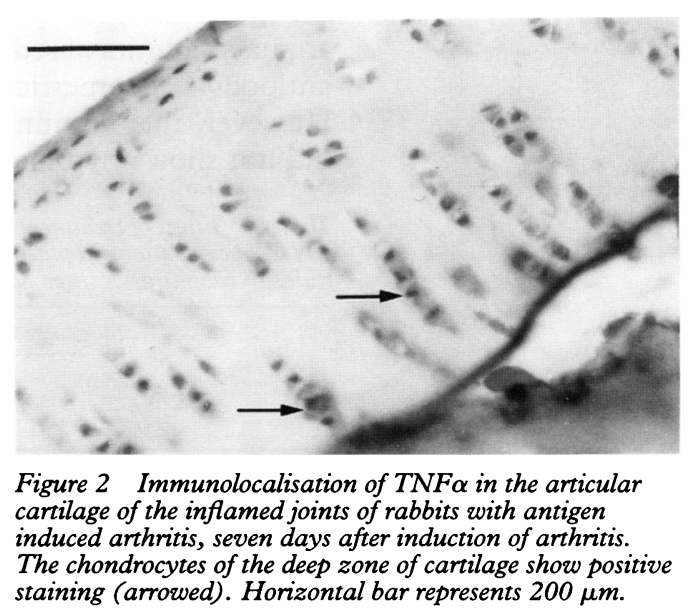




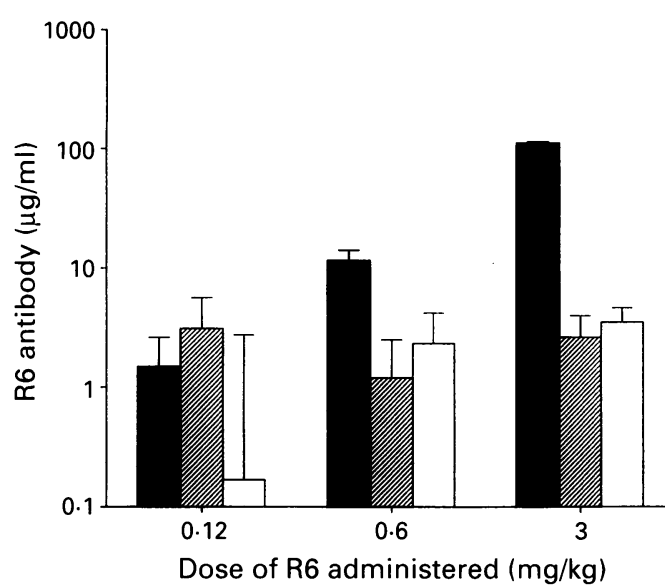

Figure 3 Effect of dosage on the concentration of rat

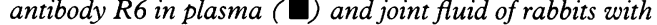
antigen induced arthritis ( $\square$ ) and non-arthritic control joints ( $\square)$, taken from animals at the end of three days of treatment (24 hours after the last administration of antibody). Results are geometric mean and $S E(n=5)$.

stronger staining of $\mathrm{TNF} \alpha$ in the deep zone chondrocytes, whereas chondrocytes in the mid- and superficial zones of cartilage remained unstained.

EFFECT OF TREATMENT WITH ANTI-TNF MONOCLONAL ANTIBODIES ON ACUTE ANTIGEN INDUCED ARTHRITIS

The levels of antibody R6 in the circulation at 72 hours were dose dependent and varied from $1.5 \mu \mathrm{g} / \mathrm{ml}$ to $112 \mu \mathrm{g} / \mathrm{ml}$ as the dose of antibody administered increased from $0.12 \mathrm{mg} / \mathrm{kg}$ to $3 \mathrm{mg} / \mathrm{kg}$. With the smallest dose of antibody there was little R6 in the control (non-arthritic) joint fluid. However, there were substantial amounts of antibody in the arthritic joint which, allowing for the dilution effect produced by the collection of the joint fluid, was at a greater concentration than was present in plasma. In contrast, with the larger doses of antibody the levels of R6 in the control and arthritic joints were similar (fig 3).

TNF $\alpha$ CONCENTRATIONS IN PLASMA AND JOINT FLUIDS

Concentrations of immunoreactive $\mathrm{TNF} \alpha$ in the plasma of saline treated control rabbits were small, but a high concentration was found in those animals treated with R6. Surprisingly, the greatest $T N F \alpha$ reactivity was in those animals administered the smallest dose of antibody (geometric mean $175 \mathrm{pg} / \mathrm{ml}$ ). However, this immunoreactive plasma TNF $\alpha$ did not show any bioactivity in the L929 cyto-

Table 1 Effect of treatment with anti-TNF $\alpha$ (R6) on $T N F$ concentrations in plasma and arthritic control joint fluids of rabbits after three days of antigen induced arthritis

\begin{tabular}{lccl}
\hline \multicolumn{4}{c}{ Immunoreactive TNF $(\mathrm{pg} / \mathrm{ml})$} \\
\cline { 2 - 4 } & Plasma & $\begin{array}{l}\text { Arthritic } \\
\text { joint } \\
\text { fluid }\end{array}$ & $\begin{array}{l}\text { Control } \\
\text { joint } \\
\text { fluid }\end{array}$ \\
\hline Saline & $35 \cdot 3(1 \cdot 1)$ & $4 \cdot 9(2 \cdot 4)$ & $10(1 \cdot 6)$ \\
$\mathrm{R} 60 \cdot 12 \mathrm{mg} / \mathrm{kg}$ & $175(1 \cdot 3)$ & $160(1 \cdot 6)$ & $8 \cdot 7(1 \cdot 2)$ \\
$\mathrm{R} 60 \cdot 6 \mathrm{mg} / \mathrm{kg}$ & $48 \cdot 9(1 \cdot 8)$ & $53 \cdot 2(1 \cdot 2)$ & $5 \cdot 1(1 \cdot 1)$ \\
$\mathrm{R} 63 \mathrm{mg} / \mathrm{kg}$ & $26 \cdot 2(1 \cdot 6)$ & $24 \cdot 3(1 \cdot 8)$ & $6 \cdot 5(2 \cdot 1)$ \\
\hline
\end{tabular}

Values are geometric mean (SE) for five rabbits.

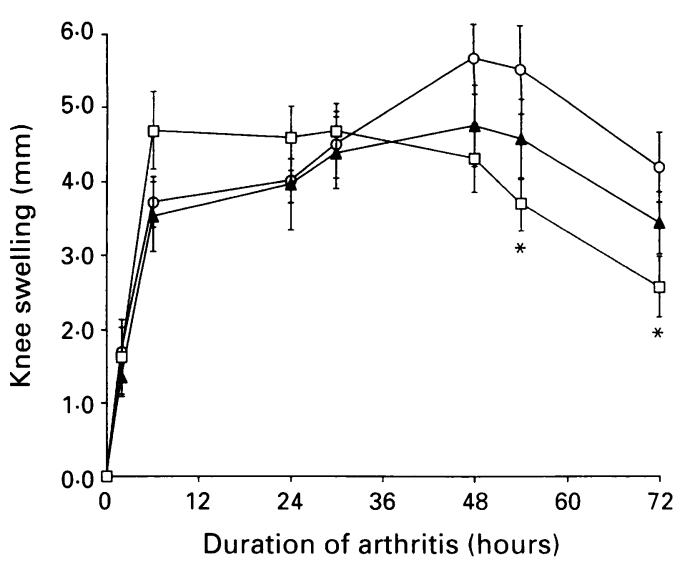

Figure 4 Effect of three days treatment with anti-TNF $\alpha$ (R6) on joint swelling in rabbits with antigen induced arthritis administered saline (O) $0.12 \mathrm{mg} / \mathrm{kg} \mathrm{R6}(\boldsymbol{\Delta})$ or $0.6 \mathrm{mg} / \mathrm{kg} \mathrm{R6}$ ( $\square$ ). Results are combined from two experiments and represent mean (SE) of differences between arthritic and control knees $(n=10) .{ }^{\star} p<0.05$ compared with saline treated control group.

toxicity assay. The concentrations of immunoreactive $\mathrm{TNF} \alpha$ in the control joint fluid from rabbits treated with anti-TNF $\alpha$ were small and were similar at all doses of antibody. In contrast, amounts of immunoreactive $\mathrm{TNF} \alpha$ in the arthritic joints were similar to circulating concentrations and increased 18-fold in animals administered the smallest dose of antibody and four to 10-fold in animals administered 0.6 or $3 \mathrm{mg} / \mathrm{kg} \mathrm{R6}$ (table 1). As with the plasma TNF, this immunoreactive $\mathrm{TNF} \alpha$ in joint fluid showed no bioactivity in the L929 assay.

\section{JOINT SWELLING}

Animals given antibody $\mathrm{R} 6 \quad 0.12 \mathrm{mg} / \mathrm{kg}$ or $0.6 \mathrm{mg} / \mathrm{kg}$ each day over the first three days of the arthritis showed a dose dependent inhibition of swelling (fig 4). Up to $40 \%$ inhibition of joint swelling was achieved in animals administered $0.6 \mathrm{mg} / \mathrm{kg}$ of antibody. In a second experiment animals received $0 \cdot 12,0 \cdot 6$ or $3 \mathrm{mg} / \mathrm{kg} \mathrm{R} 6$, but the fivefold greater dose gave no greater effect than $0.6 \mathrm{mg} / \mathrm{kg}$ (data not shown).

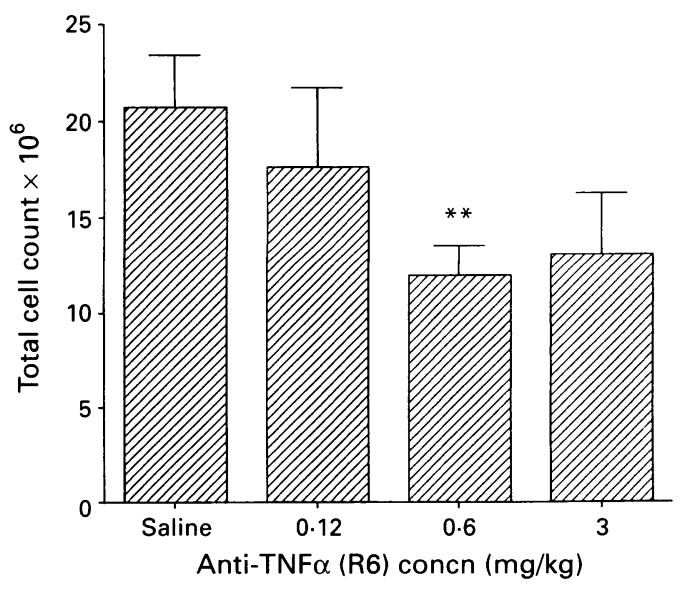

Figure 5 Effect of three days treatment with anti-TNF $\alpha$ (R6) on leucocyte accumulation in the synovial joint space of animals with antigen induced arthritis. Results are combined from two experiments and represent mean and SE $(n=10) .{ }^{\star \star} p<0.01$ compared with saline treated control. group. 
Table 2 Effect of treatment with anti-TNF $\alpha$ (R6) on the expression of CD11b and CD18 on infiltrating leucocytes in the synovial fluid of rabbits after three days of antigen induced arthritis

\begin{tabular}{|c|c|c|c|c|}
\hline & \multicolumn{4}{|c|}{ Subunit (\% positive fluorescence) } \\
\hline & \multicolumn{2}{|l|}{$C D 11 b$} & \multicolumn{2}{|l|}{$C D 18$} \\
\hline & Lymphocytes & Mono/Macro & Lymphocytes & Mono/Macro \\
\hline $\begin{array}{l}\text { Saline } \\
\text { R6 } 0.12 \mathrm{mg} / \mathrm{kg} \\
\text { R6 } 0.6 \mathrm{mg} / \mathrm{kg}\end{array}$ & $\begin{array}{l}87.9(0 \cdot 8) \\
76.5(9.9) \\
63.7(1.9)^{\star}\end{array}$ & $\begin{array}{l}82 \cdot 3(2 \cdot 1) \\
88 \cdot 8(3.4) \\
68 \cdot 9(4 \cdot 5)\end{array}$ & $\begin{array}{l}75 \cdot 3(3 \cdot 5) \\
65 \cdot 3(8 \cdot 7) \\
58 \cdot 3(1 \cdot 2)^{\star}\end{array}$ & $\begin{array}{l}63 \cdot 7(5 \cdot 2) \\
65 \cdot 9(5 \cdot 5) \\
58 \cdot 5(4 \cdot 7)\end{array}$ \\
\hline
\end{tabular}

Values are mean $(\mathrm{SE})(\mathrm{n}=5)$. Mono/Macro $=$ Monocytes $/$ macrophages. ${ }^{\star} \mathrm{p}<0.05$ compared with saline treated control group.

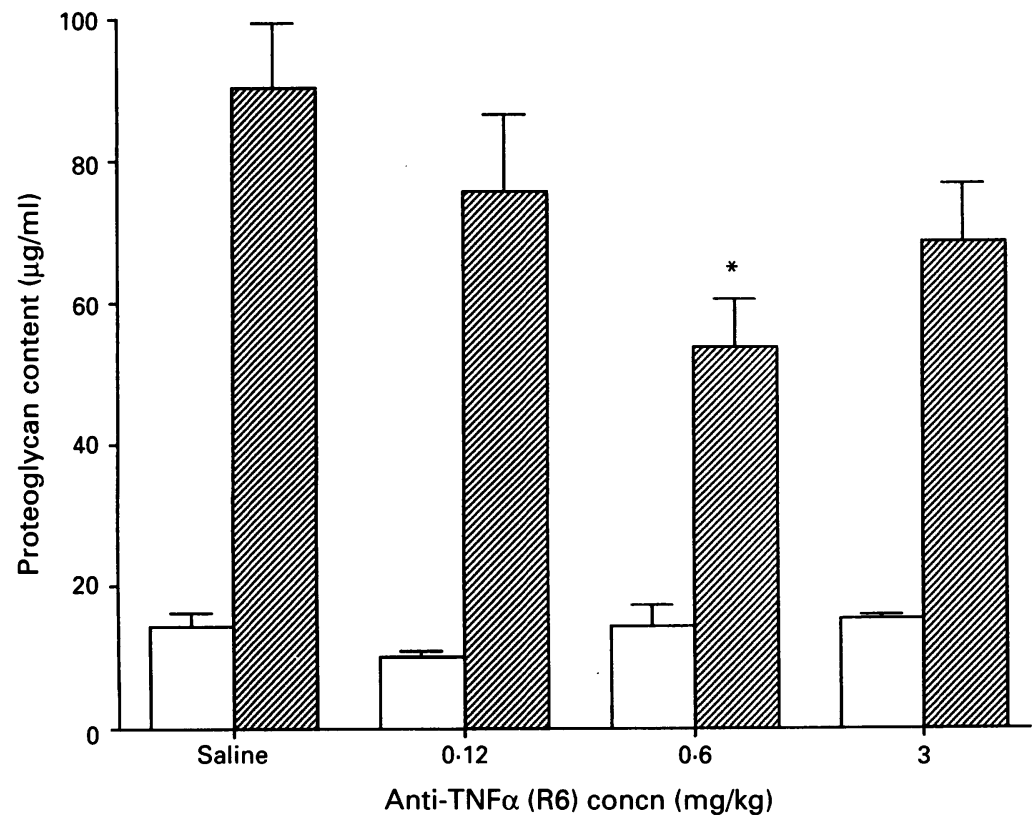

Figure 6 Effect of three days treatment with anti-TNF $\alpha(R 6)$ on the proteoglycan content of the control $(\square)$ and arthritic $(\square)$ joint fluids of rabbits with antigen induced arthritis. Results are mean and $S E(n=10) .{ }^{{ }} p<0.05$ compared with saline treated control group.

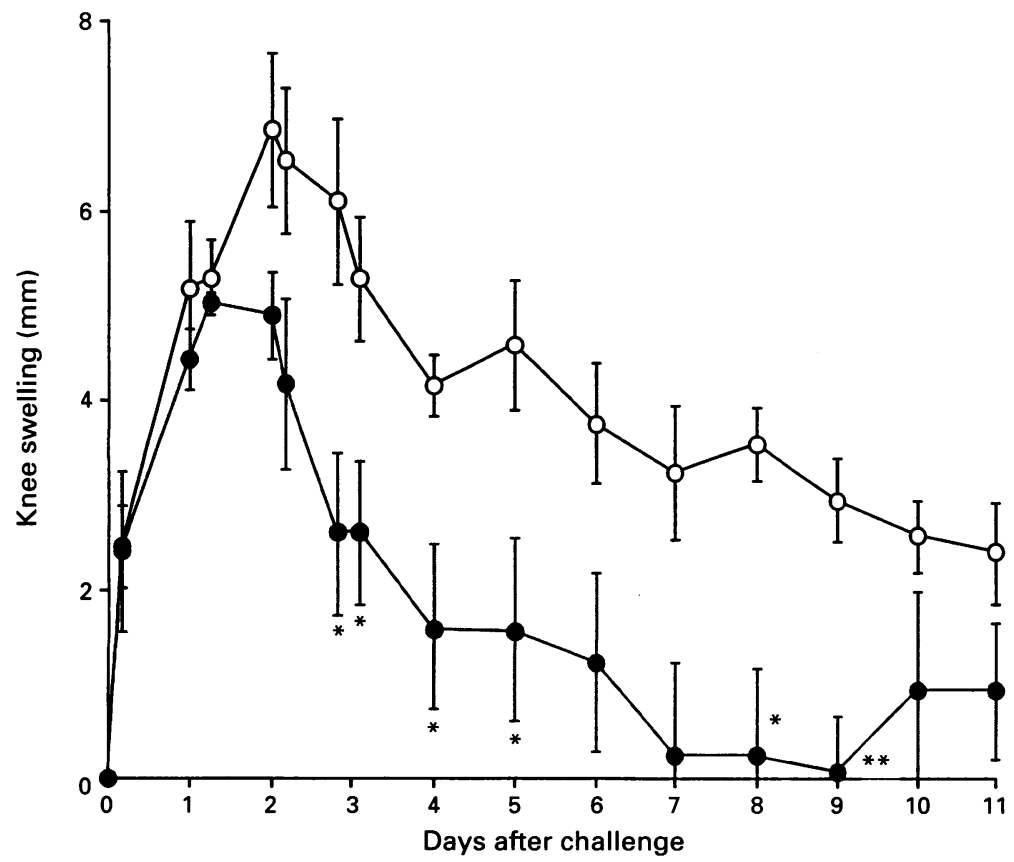

Figure 7 Effect of 10 days treatment with anti-TNF $\alpha$ (R6) on joint swelling in rabbits with antigen induced arthritis administered either $0.6 \mathrm{mg} / \mathrm{kg} \mathrm{R6}$ daily for 10 days beginning one day after the induction of arthritis (O) or saline for the same period (O). Results are expressed as mean and $S E$ of differences between arthritic and control knees $(n=5)$. ${ }^{\star} p<0.05,{ }^{\star} p<0.01$ compared with saline treated control groups.
LEUCOCYTE ACCUMULATION AND JOINT FLUID CHANGES

The administration of neutralising anti-TNF $\alpha$ antibody reduced the accumulation of leucocytes in the joint fluid with a maximal reduction $(42 \%)$ at $0.6 \mathrm{mg} / \mathrm{kg} \mathrm{R6}$ (fig 5 ). As with the effect on joint swelling, increasing the concentration of neutralising antibody fivefold gave no further reduction in leucocyte infiltration into the joint fluid. As determined by FACS analysis, antibody R6 caused a significant reduction in the expression of the $\beta_{2}$ integrin subunits $\mathrm{CD} 1 \mathrm{lb}$ and $\mathrm{CD} 18$ on lymphocyte sized cells in the synovial cavity, but did not significantly reduce their expression on monocyte/macrophage sized cells in the arthritic joints (table 2).

The concentrations of $\mathrm{PGE}_{2}$ in fluids from the arthritic joints were more than twice those of the controls. Administration of R6 in any dose did not result in a significant reduction $\mathrm{PGE}_{2}$ although a smaller average concentration was found in animals given $3 \mathrm{mg} / \mathrm{kg}$ antibody (table 3).

After three days of arthritis, increased amounts of proteoglycan fragments (GAG) were detected in the arthritic joint fluid compared with controls. In both experiments with R6, there was a significant reduction of joint fluid proteoglycan content with R6 $0.6 \mathrm{mg} / \mathrm{kg}$ (fig 6). In AIA there is a rapid loss of proteoglycan content of the articular cartilage over the first three days, which in these experiments averaged $30 \%$. Administration of anti-TNF antibodies at all doses over three days failed to show any significant reduction in this net loss of cartilage proteoglycan (results not shown).

\section{CHRONIC DOSING OF RABBITS WITH}

MONOCLONAL ANTIBODY R6

Daily injection of R6 $0.6 \mathrm{mg} / \mathrm{kg}$ from one to 10 days after induction of arthritis resulted in a more sustained effect on joint swelling; swelling was reduced to control values between days 7 and 9 (fig 7), but then showed some renewal at days 10 and 11 . To determine if treatment led to prolonged suppression of arthritis, the animals received $\mathrm{R} 6$ daily for five days between one and five days after joint challenge and were then left for a further 16 days without antibody administration. There was an initial significant inhibition of joint swelling, reaching a maximum of $70 \%$ $(\mathrm{p}<0.01)$ at day 5 and the reduction remained statistically significant up to day 11 . However, this effectiveness was not sustained from day 11 to day 21 . While administration of R6 for

Table 3 Effect of treatment with anti-TNF $\alpha$ (R6) on the concentration of prostaglandin $E_{2}$ in arthritic and control joint fluids of rabbits after three days of antigen induced arthritis

\begin{tabular}{lll}
\hline & \multicolumn{2}{l}{ Prostaglandin $E_{2}(\mathrm{ng} / \mathrm{ml})$} \\
\cline { 2 - 3 } & Arthritic joint fluid & Control joint fluid \\
\hline Saline & $6.3(1 \cdot 8)$ & $2 \cdot 6(0.5)$ \\
$\mathrm{R} 60.12 \mathrm{mg} / \mathrm{kg}$ & $6.4(1.5)$ & $2 \cdot 5(0 \cdot 4)$ \\
$\mathrm{R} 60.6 \mathrm{mg} / \mathrm{kg}$ & $5 \cdot 7(1.1)$ & $2 \cdot 5(1 \cdot 3)$ \\
$\mathrm{R} 63 \mathrm{mg} / \mathrm{kg}$ & $3.6(0.8)$ & $1.5(0 \cdot 8)$ \\
\hline
\end{tabular}

Values are mean $(\mathrm{SE})$ for five rabbits. 
five or 10 days inhibited joint swelling, it did not produce significant reduction in the number of leucocytes in the arthritic joints, or in the loss of proteoglycan from cartilage in either group.

RABBIT ANTI-RAT ANTIBODY RESPONSE IN ANTITNF TREATED RABBITS

Animals given R6 for five days and then killed at day 21 showed very high titres of circulating antibodies to rat IgG (rabbit anti-rat antibody).

\section{Discussion}

Antigen induced arthritis in the rabbit is a monoarticular lesion in which, unlike many other models of arthritis, the inflammation becomes chronic and has been reported to last more than two years. ${ }^{26}$ The pattern of tissue damage and the pathological changes in the inflamed synovial lining are similar to those found in $\mathrm{RA}^{14}$ and the response of the model to currently used anti-inflammatory and antiarthritic drugs is similar to that found in RA. ${ }^{27}$

TNF $\alpha$ has been proposed to be a major mediator of the tissue pathology of rheumatoid arthritis. ${ }^{28}$ In this study we have examined the tissues from inflamed joints of rabbits for the presence of TNF $\alpha$ during the first three weeks of AIA. It was surprising that immunoreactive $\mathrm{TNF} \alpha$ could only be detected at low concentration in joint fluids at one day after induction of arthritis and not subsequently, although this is similar to results reported for bioactive IL-1 levels, which were high at 24 hours after induction, but rapidly decreased below the level of detection. ${ }^{29}$ The antibody R6 was used to immunolocalise $\mathrm{TNF} \alpha$ in synovium and articular cartilage of rabbits with AIA. In the inflamed synovium small numbers of specifically stained cells were detectable in the subintima from day 3 onwards. However, no staining could be detected in the synovial lining cell population, or in vascular endothelial cells, as has been reported in human RA synovium. ${ }^{830} \mathrm{~A}$ surprising finding was that the articular cartilage, taken from the arthritic joints at day 3 or later, contained TNF localised in the chondrocytes in the deep zone of the cartilage, but not in the mid-zone or superficial layers. Indeed, from the numbers of cells stained and the intensity of the staining, it appeared that the chondrocytes could be an important source of $\mathrm{TNF}_{\alpha}$ in the arthritic joints. Why the staining should be confined to this deep zone is not clear, but it may suggest that TNF-inducing signals come from the subchondral bone. No immunoreactive TNF $\alpha$ could be detected in non-arthritic control joint fluids and no TNF $\alpha$ was immunolocalised in tissues taken from control joints. In view of the effects of anti-TNF $\alpha$ in suppressing the arthritis, it was interesting that TNF $\alpha$ was not detected in the arthritic tissues. This suggests that TNF $\alpha$ may be present in the tissues in concentrations sufficient to give important biological effects, but too small for immunolocalisation.
Administration of R6 over a three day period had several effects. There was an inhibition of joint swelling, which was greatest with the $0.6 \mathrm{mg} / \mathrm{kg}$ dose of antibody at 72 hours. This inhibition of joint swelling induced by R6 occurred more rapidly than that induced in this model by anti-inflammatory drugs such as indomethacin ${ }^{31}$ or prednisolone, ${ }^{32}$ and was not associated with inhibition of the levels of $\mathrm{PGE}_{2}$ in the synovial fluid. There was also a reduction in leucocyte accumulation of $42 \%$ with the $0.6 \mathrm{mg} / \mathrm{kg}$ dose of R6. Increasing the dose of antibody fivefold to $3 \mathrm{mg} / \mathrm{kg}$ had no further effect on either of these measures of inflammation. Thus $\mathrm{TNF} \alpha$, or some mediator dependen on the activity of this cytokine, appeared to be responsible, at least in part, for the joint swelling and leucocyte infiltration seen in the early phase of this model. Neutralisation of $\mathrm{TNF} \alpha$ also had a significant inhibitory effect on the expression of CD18 and CD11b in the lymphocyte sized cells, but not in macrophage/monocyte sized cells, collected from the arthritic joints, which suggested some suppression of lymphocyte activation. Anti-CD18 antibodies have been shown to reduce leucocyte infiltration into joint fluid $(>90 \%)$ and the severity of the chronic synovitis in this model of arthritis. ${ }^{33}$ In our study the partial inhibition of CD11b, CD 18 on cells, caused by anti-TNF $\alpha$ may therefore contribute to the decrease in leucocyte infiltration, although there was no apparent reduction in synovitis. Further antiinflammatory effects can also be inferred from the measurement of the levels of R6 in plasma and joint fluid. In animals given the smallest dose of R6 there was a substantial amount of antibody in the arthritic joint, but little in the control joint. This presence of antibody in the arthritic joint was presumably a result of an increase in local vascular permeability. With animals given the 0.6 or $3 \mathrm{mg} / \mathrm{kg}$ doses of antibody, the levels of antibody detected in the plasma were 7.7 and 74.4 times greater, respectively. In spite of this, the antibody levels in the joint fluid were smaller than in animals given $0.12 \mathrm{mg} / \mathrm{kg} \mathrm{R6}$. This suggests that greater levels of the antibody inhibited the vascular leakage in the arthritic joint, so that antibody did not concentrate in the joint space. The inhibition of vascular leakage by R6 may also contribute to the reduction in joint swelling.

When R6 was administered for longer periods there was more pronounced reduction of joint swelling, which was completely inhibited between seven and nine days, although it started to increase thereafter. This inhibition of swelling is striking and suggests that TNF or TNF dependent mediators are also responsible for the persistence of the joint swelling in the chronic phase of this model. Administration of R6 from day 1 to day 5 after induction of arthritis significantly inhibited joint swelling between days 2 and 11 (results not shown), but there was a gradual return of joint swelling after longer periods. This experiment demonstrates that the effects of R6 were not permanent, although some inhibition 
of joint swelling extended well beyond the short term administration of the antibody.

In animals administered R6 for five or 10 days there was little effect on reducing accumulation of leucocytes or cartilage breakdown. The failure to block these processes may be attributable in part to the formation of a rabbit immune response to the administered rat antibody. This may have neutralised the activity of the therapeutic $M A b$, as no R6 could be detected at day 11 in animals administered antibody from day 1 to day 10 , implying that it was rapidly cleared, possibly because of a rabbit anti-rat antibody response. Indeed, very large amounts of rabbit anti-rat IgG were found in animals administered antibody for five days and examined 16 days later-21 days after the induction of arthritis. In using this rat anti-rabbit $\mathrm{TNF} \alpha$ antibody there has been no attempt to make it well tolerated by the rabbits. There was a rabbit anti-rat immune response and this was sufficient to interfere with its long term therapeutic action in this study, and may have contributed to the lack of increased effectiveness in larger dosage $(3 \mathrm{mg} / \mathrm{kg}$ ).

The concentrations of immunoreactive $\mathrm{TNF} \alpha$ in the plasma and in synovial fluids from inflamed joints at three days were very much greater in animals administered antibody than in untreated animals. However, there was no increase in immunoreactive $\mathrm{TNF} \alpha$ in the aspirates from the control joints. The reason for this increase is unclear. It may reflect the formation of anti-TNF $\alpha$ immune complexes, which are cleared much more slowly than free $\mathrm{TNF} \alpha$ and therefore accumulate. Such complexes would be detected in the two site assay used and R6 was clearly also present in the joint at this time. The absence of TNF $\alpha$ bioactivity supports this explanation and confirms that $\mathrm{R} 6$ can neutralise $\mathrm{TNF} \alpha$ in vivo.

Acute administration of a neutralising antiTNF $\alpha$ antibody during the first three days of arthritis had a clear effect on inflammation in the joint. As the inhibition of joint swelling and leucocyte infiltration was incomplete, this suggests that the antibody was unable to penetrate to all sites of TNF production or action, or that other mediators, not associated with the actions of $T N F \alpha$, contribute to the remaining inflammatory response, or that the antibody was in insufficient excess to block the peak of TNF $\alpha$ production. In spite of the ability to inhibit leucocyte accumulation, the neutralisation of $\mathrm{TNF} \alpha$ had no significant effect on the loss of proteoglycan from articular cartilage. There are some possible explanations for this. First, the antibody may not penetrate the cartilage sufficiently to neutralise the $\mathrm{TNF} \alpha$, which was localised in the deep zone chondrocytes early in this disease. Indeed, it is established that normal cartilage is impermeable to most molecular species larger than $60 \mathrm{kDa} \cdot{ }^{34}$ If cartilage destruction is caused by autocrine stimulation within the mass of the cartilage, treatment with anticytokine antibodies may not easily prevent it. This problem might, of course, be overcome by the use of lower molecular weight antibody constructs, such as $F a b$ or $F(a b)_{2}$, which would increase cartilage penetration. Second, $\mathrm{TNF} \alpha$ may not be the major cytokine which causes cartilage proteoglycan loss, although our previous results with IL-1ra (which is of low molecular weight) showed that blocking IL-1 was even more ineffective in preventing proteoglycan loss from cartilage. ${ }^{13}$ It is also of interest that, as we have shown in previous studies, ${ }^{35}$ there is no correlation between the numbers of infiltrating cells in the joint and the damage to articular cartilage. Thus there is little evidence of any close correlation between the factors that determine leucocyte infiltration into the joint and those that cause damage to cartilage and bone, which also implies that success in reducing inflammation cannot be taken as an indicator of similar success in preventing tissue damage.

An encouraging finding in this context was the decrease in cartilage proteoglycan fragments in the synovial fluid on day 3 in animals treated with R6. This may reflect a small inhibition of cartilage breakdown at the end of three days of treatment, at a time when the major peak of $\mathrm{TNF} \alpha$ production has passed, but this was too modest an effect to reduce significantly the net loss over the first three days.

In conclusion, administration of a neutralising antibody to rabbit $\mathrm{TNF} \alpha$ to rabbits with antigen induced arthritis has a significant anti-inflammatory effect and can completely block joint swelling. However, under the conditions tested the treatment did not inhibit the acute loss of proteoglycan from cartilage. It may require more effective $\mathrm{TNF} \alpha$ blockade, with better penetration of the tissues, to inhibit the chondrocyte cytokine network which may be inducing the damage to the cartilage matrix.

This work was carried out with support from the Arthritis and Rheumatism Council (UK), the Nuffield Foundation (UK) and Celltech (Slough, UK).

1 Dayer J-M, Beutler B, Cerami A. Cachectin/tumour necrosis factor stimulates collagenase and prostaglandin $\mathrm{E}_{2}$ production by human synovial cells and dermal fibroblasts. $\mathcal{F}$ Exp Med 1985; 162: 2163-8.

2 Pober J S, Gimbrone M A, Lapierre L A, et al. Overlapping patterns of activation of human endothelial cells by interleukin-1, tumor necrosis factor, and immune interferon. F Immunol 1986; 137: 1893-6.

3 Saklatvala J. Tumour necrosis factor- $\alpha$ stimulates resorption and inhibits synthesis of proteoglycan in cartilage. Natur 1986; 322: 547-9.

4 Bertolini D R, Nedwin G E, Bringman T S, Smith D D Mundy $G R$. Stimulation of bone resorption and inhibition of bone formation in vitro by human tumo necrosis factors. Nature 1986; 319: 516-8.

5 Vilcek J, Palombella V J, Henriksen-DeStafano D, et al. Fibroblast growth enhancing activity of tumour necrosis factor and its relationship to other polypeptide growth factors. F $\operatorname{Exp}$ Med 1986; 163: 632-43.

$6 \mathrm{Di}$ Giovine F S, Nuki G, Duff G. Tumour necrosis factor in synovial exudates. Ann Rheum Dis 1988; 47: f68-72.

7 Wilkinson L S, Edwards J C W. Binding of antibodies raised against tumour necrosis factor (TNF $\alpha$ ) to blood vessels and macrophages in inflamed synovial tissue. Rheumatol Int 1991; 11: 19-25.

8 Firestein G S, Alvaro-Garcia J M, Maki R. Quantitative analysis of cytokine gene expression in rheumatoi arthritis. F Immunol 1990; 144: 3347-53.

9 Keffer J, Probert L, Cazlaris $\mathrm{H}$, et al. Transgenic mice expressing human tumour necrosis factor: a predictive genetic model of arthritis. EMBO f 1991; 10: 4025-31.

10 Pettipher E R, Higgs G A, Henderson B. Interleukin-1 induces leukocyte infiltration and cartilage proteoglycan degradation in the synovial joint. Proc Natl Acad Sci USA 1986; 83: 8749-53. 
11 Henderson B, Pettipher E R. Arthritogenic actions of recombinant interleukin-1 and tumour necrosis factor alpha in the rabbit: evidence for synergistic interactions between cytokines in vivo. Clin Exp Immunol 1989; 75: 306-10.

12 Henderson B, Thompson $\mathrm{R}$ C, Hardingham $\mathrm{T}$, Lewthwaite $\mathrm{J}$. Inhibition of interleukin-1-induced synovitis and articular cartilage proteoglycan loss in the rabbit knee by recombinant human interleukin-1 receptor antagonist. Cytokine 1991; 3: 246-9.

13 Lewthwaite J, Blake S M, Hardingham T E, Warden P J, Henderson B. The effect of recombinant human interleukin-1 receptor antagonist on the induction phase of antigen-induced arthritis in the rabbit. 7 Rheumatol 1994; 21: 467-72.

14 Henderson B, Glynn L E. Metabolic alterations in the synoviocytes in chronically inflamed knee joints in synoviocytes in chronically inflamed knee joints in toid arthritis. Br f Exp Pathol 1981; 62: 27-33.

15 Bowen J G, Crossley M J, Hunneyball I M. Diseasemodifying anti-rheumatic drugs: Strategies for screening. Pharmacol Ther 1992; 56: 287-306.

16 Flick D A, Gifford G E. Comparison of in vitro cell cytotoxicity assays for tumour necrosis factor. $\mathcal{F}$ Immunol Methods 1984; 68: 167-75.

17 Ruff M R, Gifford G E. Purification and physico-chemical characterisation of rabbit tumour necrosis factor. 7 Immunol 1980; 125: 1671-7.

18 Haranaka K, Salomi N, Nariuchi H. Purification and partial amino acid sequence of rabbit tumour necrosis factor. Int a Cancer 1985; 36: 395-400

19 Adams B, Regenass U, Cerletti N. An efficient method for the purification of tumour necrosis factor from rabbit the purification of tumour necrosis facto
serum. Lymphokine Res $1987 ; 6: 203-14$

20 Ito H, Yamamoto S, Kuroda S, et al. Molecular cloning and expression in $E$. coli of the cDNA coding for rabbit tumor necrosis factor. DNA 1986; 5: 149-56.

21 Wright E M, Humphreys G O, Yarranton G T. Dual origin plasmids containing an amplifiable ColEl ori: temperature-controlled expression of cloned genes. Gene 1986; 49: 311-21.

22 Colcher D, Milenic D, Roselli M, et al. Characterization and biodistribution of recombinant and recombinant/chimeric constructs of monoclonal antibody B72.3. Cancer Res 1989; 49: $1738-45$.
23 Polak J M, van Noorden S. Immunocytochemistry. Elsevier: North Holland, 1986.

24 Ratcliffe A, Doherty M, Maini R N, Hardingham T E. Increased concentration of proteoglycan components in the synovial fluid of patients with acute but not chronic joint disease. Ann Rheum Dis 1988; 47: 826-32.

25 Farndale R W, Buttle D J, Barrett A J. Improved quantitation and discrimination of sulphated glycosaminoglycans by use of dimethylmethylene blue. Biochim Biophys Acta 1986; 883: 173-7.

26 Consden R, Doble A, Glynn L E, Nind A P. Production of chronic arthritis with ovalbumin. Its retention in the knee joint. Ann Rheum Dis 1971; 30: 307-15.

27 Billingham M E J. Models of arthritis and the search for anti-arthritic drugs. Pharmacol Ther 1983; 21: $389-428$

28 Brennan F M, Jackson A, Chantry D, Maini R, Feldmann $M$. Inhibitory effect of TNF-alpha antibodies on synovial cell interleukin-1 production in rheumatoid arthritis. Lancet 1989; $2: 244-7$

29 Henderson B, Rowe F M, Bird C R, Gearing A J H. Production of interleukin-1 in the joint during the development of antigen-induced arthritis in the rabbit. Clin Exp Immunol 1988; 74: 371-6.

30 Husby G, Williams R C. Synovial localization of tumor necrosis factor in patients with rheumatoid arthritis. f Autoimmunity 1988; 1: 363-71.

31 Pettipher E R, Henderson B, Edwards J C W, Higgs G A Effect of indomethacin on swelling, lymphocyte influx and cartilage proteoglycan depletion in experimental arthritis. Ann Rheum Dis 1989; 48: 623-7.

32 Henderson B, Hardingham T, Blake S, Lewthwaite J. Experimental arthritis models in the study of the
mechanisms of articular cartilage loss in rheumatoid mechanisms of articular cartilage loss in rheu

33 Jasin H E, Lightfoot E, Davis L S, Rothlein R, Fanes R B Lipsky P E. Amelioration of antigen-induced arthritis in rabbits treated with monoclonal antibodies to leukocy adhesion molecules. Arthritis Rheum 1992; 13: 327-31.

34 Maroudas A. Transport of solutes through cartilage: permeability to large molecules. F Anat 1976; 122: 335-47.

35 Pettipher E R, Henderson B, Moncada S, Higgs G A Leucocyte infiltration and cartilage proteoglycan loss in immune arthritis in the rabbit. Brf Pharmacol 1988; 95. $169-76$. 